\title{
Anticipated Verbal Feedback Induces Altruistic Behavior
}

\author{
Tore Ellingsen \\ Department of Economics, Stockholm School of Economics, Box 6501, SE-113 83 \\ Stockholm, Sweden; e-mail: tore.ellingsen@hhs.se \\ Magnus Johannesson \\ Department of Economics, Stockholm School of Economics, Box 6501, SE-113 83 \\ Stockholm, Sweden; e-mail: magnus.johannesson@hhs.se
}

SSE/EFI Working Paper Series in Economics and Finance

No. 668

June, 2007

\begin{abstract}
A distinctive feature of humans compared to other species is the high rate of cooperation with non-kin. One explanation is that humans are motivated by concerns for social esteem. In this paper we experimentally investigate the impact of anticipated verbal feedback on altruistic behavior. We study pairwise interactions in which one subject, the "divider", decides how to split a sum of money between herself and a recipient. Thereafter, the recipient can send an unrestricted anonymous message to the divider. The subjects' relationship is anonymous and one-shot to rule out any reputation effects. Compared to a control treatment without feedback messages, donations increase substantially when recipients can communicate. With verbal feedback, the fraction of zero donations decreases from about $40 \%$ to about $20 \%$, and there is a corresponding increase in the fraction of equal splits from about $30 \%$ to about $50 \%$. Recipients who receive no money almost always express disapproval of the divider, sometimes strongly and in foul language. Following an equal split, almost all recipients praise the divider. The results suggest that anticipated verbal rewards and punishments play a role in promoting altruistic behavior among humans.
\end{abstract}

Key words: Punishment, Approval, Disapproval, Dictator game, Altruism, Communication, Verbal feedback.

JEL Codes: C91, D64.

Acknowledgement: We thank Emma Mårtensson and Björn Tyrefors for research assistance. We also thank The Torsten and Ragnar Söderberg Foundation, The Jan Wallander and Tom Hedelius Foundation, and the Swedish Research Council for financial support. 


\section{INTRODUCTION}

Human altruism is considered an evolutionary puzzle (Nowak 2006). ${ }^{1}$ While repeated interaction and reputation formation can explain altruistic behavior in small closely-knit groups, altruism is often considerable among strangers who interact only once. Here, we investigate the hypothesis that altruism is caused by feelings of shame and pride and that these feelings are accentuated by others' verbal evaluation.

Our evidence comes from a dictator game experiment with recipient feedback. We find that the opportunity for verbal feedback substantially increases donations compared to a control treatment without any feedback.

In a typical dictator game, one person (the divider) is in charge of dividing a resource between herself and another person (the recipient). Usually, the resource is an amount of money, and the divider is free to choose any division. While nothing prevents the divider from taking all the money, a substantial fraction of the dictators leaves some money to the recipient. In laboratory experiments in Western cultures, the equal split is the second most common allocation, with the average donation typically falling in the interval $10-30 \%$ (Camerer, 2003). Henrich et al. (2004) report similar results from subject pools that are isolated from Western culture.

There are several reasons for thinking that generosity in dictator games is driven by a desire for social esteem. When the divider's choice is observable to the experimenter (Hoffman et al., 1994) and to the recipient (Dana et al., 2006; Andreoni and Bernheim, 2006), the division becomes more generous. Even pictures of eyes, subtly triggering a sense of being watched, has a significant positive impact on generosity in both laboratory experiments (Haley and Fessler, 2005) and field settings (Bateson, Nettle, and Roberts, 2006). This

\footnotetext{
1 Selfless or altruistic behavior is here defined as refraining from gaining personal advantage at another's expense. Cooperation results when several people engage in altruistic behavior.
} 
evidence is congruent with the long-standing view that prosocial behavior is fuelled by the desire to feel (justified) pride and to avoid feeling shame, ${ }^{2}$ and more generally with the desire to signal favorable characteristics. ${ }^{3}$ Importantly, these are not loose associations. Andreoni and Bernheim (2006) formally demonstrate that a signaling model predicts the observed spikes in dictator game data.

We hypothesize that feelings of shame and pride are accentuated by emotional communication. Knowing that someone is angry does not arouse the same level of shame as facing the angry person. Likewise, feelings of justified pride are accentuated by laudatory speeches, even if the speeches contain no new information. If so, altruistic behavior ought to increase when recipients can provide verbal feedback. The recipient's approval is a symbolic reward; the recipient's disapproval is a symbolic punishment. Consistent with our hypothesis, work in social psychology indicates that feedback in the form of praise raises the level of pride and satisfaction in performing a task (Webster et al. 2003; Gaines et al. 2005).

Although the applied psychology literature has found significant effects of symbolic rewards in the workplace and in schools (Henderlong and Lepper 2002; Stajkovic and Luthans 2003), such studies suffer from the problem that symbolic rewards may be correlated with subsequent material rewards. A similar objection may be directed at the few experimental studies that consider symbolic punishment in repeated public goods games (Gächter and Fehr, 1999; Masclet et al., 2003; Noussair and Tucker, 2005). While behavior does tend to become more prosocial when communication is possible, it is difficult to know whether behavior changes in order to reduce the suffering generated directly by the verbal

\footnotetext{
${ }^{2}$ See, for example, Smith (1790), Cooley (1922), and Scheff (1988). Fessler (2004) argues that pride and shame are human universals and provides an evolutionary theory of these emotions.

${ }^{3}$ For a recent survey of signaling theories of altruistic behavior, see Bliege Bird and Smith (2005).
} 
sanction or to mitigate the effect that verbal messages have on future material payoffs. ${ }^{4}$ Together with Xiao and Houser (2007) (to be discussed below) ours is the first study to isolate the impact of anticipated feedback on altruistic behavior. ${ }^{5}$

\section{EXPERIMENTAL DESIGN AND PROCEDURES}

We conduct a one-shot anonymous dictator game experiment with and without ex post recipient communication in the form of an unrestricted written message. The dictator game is chosen over the more popular ultimatum game in order to avoid confounding altruism with risk aversion or false beliefs. Moreover, we want to study the generosity of the divider rather than the recipient's willingness to engage in costly punishment. According to Koenigs et al. (2007), charity and punishment engage different parts of the brain. We choose written messages over other forms of communication both for simplicity and in order to maintain anonymity. Hatfield et al. (1995) show that many people experience strong emotional reactions to written scripts.

In both our treatments, one subject (the divider) decides how to allocate SEK 120 between herself and another subject in another room (the recipient) (SEK=Swedish Kronor; $\$ 1 \approx$ SEK 7.5 at the time of the experiment). In the feedback treatment, the recipient has the opportunity to send a message after learning the divider's allocation; in the control treatment, the recipient has no communication option.

\footnotetext{
4 Relatedly, the fact that people are generally more cooperative when they are allowed to interact face to face or merely to see their opponents, as documented by Ostrom and Walker (1997) and Bohnet and Frey (1999) respectively, could in principle be due either to increased empathy or to reputational effects.

5 The same authors, Xiao and Houser (2005), study how the possibility of feedback messages affects recipients in ultimatum games. They find that ex post verbal feedback among recipients decreased their likelihood of rejecting an unfair offer, suggesting that expression of disapproval is a substitute for monetary punishment.
} 
The subjects were recently enrolled undergraduate business and economics students at the Stockholm School of Economics. The experiment was conducted in early September 2006. Subjects were randomly allocated between the two treatments and we carried out five sessions (three with the feedback treatment and two with the control treatment). A total of 276 subjects participated in the experiment yielding 134 pairs of observations ( 85 in the feedback group and 53 in the control group). Subjects in a pair were anonymous with respect to each other, and the decision of a specific subject could not be observed by other subjects or the experimenters. The two treatments are further described below (the complete instructions are available in Appendix 2).

In the feedback group, subjects are recruited to two separate rooms called room A and room B. Dividers are in room A and recipients are in room B. The subjects are welcomed and told not to talk to each other. Subjects in both rooms receive numbered instruction sheets. Subjects in room A also receive an envelope marked with the same number that contains six SEK 20 bills. The subjects read the instructions, and thereafter they are allowed to ask questions individually and privately (after first raising their hands).

The experimenter in room A calls one person at a time and the subject takes her envelope and goes behind a screen. In private behind the screen, the subject decides how many SEK 20 bills to leave in the envelope and how many to keep for her own use. The subject then seals the envelope and drops it in a box marked "Mail". The subject thereafter returns to their seat. When all subjects in room A have made their decisions, the experimenter gives the box marked "Mail" to an assistant that is waiting outside of room A. The assistant takes the box with the envelopes to room B and distributes the envelopes to the respective recipients. Each recipient opens the envelope and pockets any money in the envelope. The recipients then writes down the amount in the envelope on a form marked "Result/Message". The recipients are told that they have the opportunity to write a message on the form and to 
thereafter put the form in the numbered envelope. The assistant then collects the envelopes and gives them to the experimenter in room A (the assistant thereafter leaves the room). The experimenter then distributes the envelopes to the dictators in room A. The dividers are told to open the envelope and read the message and thereafter to fold the "Result/Message" form, without putting it back into the envelope. The experimenter then passes around the box marked "Mail" and the dividers are told to put the folded forms into the box (the forms now lack any identification numbers and a specific form/decision cannot therefore be linked with any specific divider in room A). The experiment is then over.

In the control group, the experiment proceeds in exactly the same way until the recipients have written down the result on the results form. The recipients are told to fold the form after they have written down the amount in the envelope, and the assistant then passes around the box marked "Mail" and the recipients put the forms in the box. The experiment is then over.

\section{RESULTS}

Figure 1 shows the distribution of donations in the two treatments. On average, subjects in the control group donated $24.84 \%$ of the endowment to the recipients. In the feedback group the average donation was $34.12 \%$ of the endowment, an increase of almost $40 \%$. The difference between the groups is statistically significant at the $5 \%$ level ( $p=0.023$ according to a non parametric Mann-Whitney test; two-sided p-value). ${ }^{6}$ The fraction of subjects who donate zero decreases substantially with feedback, from $42 \%$ to $21 \%$. With feedback there is

\footnotetext{
6 The significance level is very similar if a t-test is used instead $(\mathrm{p}=0.036)$ or if a bootstrap test is used $(\mathrm{p}=0.020)$. The significance level for the bootstrap test was based on 5,099 bootstrap replications; see Ellingsen and Johannesson (2004) for a further discussion of this test.
} 
also a sizeable increase in the fraction of subjects that divide the endowment equally between the subjects. This fraction increases from $30 \%$ to $48 \%$.

The messages themselves also provide interesting information. A complete translation of all messages is provided in Appendix 1. For ease of characterization, we furthermore classify the messages according to whether they express disapproval, approval, or a neutral evaluation of the divider. All 18 recipients that received no money sent messages to the dividers, and 17 of them expressed disapproval. Many of these messages communicated strongly negative views, frequently in foul language. Of the 41 recipients that received half the endowment, 38 sent a message to the divider. All of these messages except one praised the divider. For the recipients that received amounts of $20 \%$ or $40 \%$, reactions were more mixed with about the same fractions of approval, disapproval, and neutral messages.

Generally, the message content is consistent with a desire to amplify the divider's feelings of shame and pride. An alternative explanation is that the receiver uses emotional contagion (Hatfield, Cacioppo, and Rapson, 1993) as a reward mechanism. While some of the positive messages may possibly be understood as an attempt to let the divider share the responder's feeling of happiness, the negative messages are predominantly angry. (Only two of them try to make the divider see the situation from their point of view.) It appears unlikely that the purpose of these messages is to induce anger in the divider. Instead, they are designed to elicit the unpleasant sensation of shame.

\section{DISCUSSION}

In conclusion, our study demonstrates that anticipated verbal feedback in the form of anonymous written messages induces a substantial increase in altruistic behavior towards otherwise defenseless opponents. Since an anonymous written message is a mild form of 
feedback compared to naturally occurring personal communication, the identified effect is likely to underestimate the behavioral impact of anticipated emotional feedback in more realistic settings.

Comparing the donation level in our feedback condition with ultimatum game proposals reported by Ellingsen and Johannesson (2005) for an almost identical subject pool, we find that they are both about $35 \%$. With the caveat that the comparison is not based on strict randomization, and that it neglects differential framing effects, the impact on divider behavior of anticipated verbal feedback is thus of similar average size as the effect of the recipient's punishment power in ultimatum games. Moreover, since material sanctions are themselves expressive of anger, it seems likely that some of the disciplining effect of rejections in the ultimatum game is due to the divider's desire to avoid the feeling of shame rather than just the anticipated material loss.

Independently of us, Xiao and Houser (2007) have conducted a similar study. Like us, they study a dictator game in which the recipient could send an anonymous message to the divider after the allocation decision. However, there are several design differences. Notably, Xiao and Houser restrict the set of offers to seven discrete levels, ruling out the possibility that the divider takes more than $90 \%$ of the available amount. Broadly, the findings coincide, but our effects are larger in magnitude and statistical significance, and our increase in equal splits is not matched by their data. There are several possible explanations for these differences. Xiao and Houser's offer restriction and the fact that they ask their subjects not to use foul or threatening language imply that verbal feedback is milder, and the fact that they do not insist that subjects read the messages means that the subjects can protect themselves from strongly negative feedback. The differences in findings between the experiments are thus well in line with our hypothesis. 
Our findings suggest that people feel shame and pride when considering others' opinion of them, and that they are only partially successful in managing these feelings. Others can magnify the feelings through emotional verbal feedback. Pride and shame in turn promote altruistic behavior.

Reputational theories of one-shot cooperation are sometimes attacked on the grounds that the experimental subjects understand that interaction is anonymous and therefore cannot care about their reputation. That criticism is based on the mistaken assumption that cognition completely trumps feelings. As Hagen and Hammerstein (2006, p343) memorably notes: "Young men certainly know that there is no chance they will encounter the attractive woman appearing in the Playboy centerfold, and they would truthfully and accurately affirm that they knew that the centerfold was just a picture in a magazine that they could not interact with, yet they might still become aroused by the photograph."

Our view that people are aware of their propensity to feel shame and pride, and are unable to fully control these feelings, have additional testable implications. For example, if dictator game dividers are given freedom to choose whether to read the feedback messages, generous dividers ought to be more prone to read. Likewise, the theory explains why people prefer not to obtain information about whether a self-interested action will cause harm to others, as documented by Dana, Weber, and Kuang (2006). Finally, the reputational theory has the potential to explain field evidence on cooperation in common pools. According to Ostrom (1990), such cooperation tends to be sustained primarily through the use of small symbolic fines.

The reputational theory of altruism does not logically preclude other theories, such as strong reciprocity (Gintis, 2000; Fehr, Fischbacher, and Gächter, 2002) and empathy (Batson et al. 1988; Batson and Shaw 1991; Singer et al. 2004; Fehr and Singer 2005). It seems that some people behave altruistically when all reputational cues are absent (Johannesson and 
Persson, 2000). Quite possibly, altruism is caused by several proximate mechanisms, just as the evolution of these proximate mechanisms may have been caused by several ultimate mechanisms (Nowak, 2006). 


\section{REFERENCES}

Andreoni, J. and Bernheim, B.D. Social image and the 50:50 norm. Unpublished 2006.

Bateson, M., Nettle, D. and Roberts, G. Cues of being watched enhance cooperation in a realworld setting. Biology Letters 2006, 2, 412-414.

Batson, CD., Dyck. J.L., Brandt, J.R., Batson, J.G., Powell, A.L., McMaster, M.R. and Griffit,

C. Five studies testing two new egoistic alternatives to the empathy-altruism hypothesis. Journal of Personality and Social Psychology 1988, 55, 52-77.

Batson, C.D. and Shaw, L.L. Evidence for altruism: toward a pluralism of prosocial motives. Psychological Inquiry 1991, 2, 107-122.

Bliege Bird, R. and Smith, E.A. Signaling theory, strategic interaction, and symbolic capital. Current Anthropology 2005, 46, 221-248.

Bohnet, I. and Frey, B. The sound of silence in prisoners' dilemma and dictator games. Journal of Economic Behavior and Organization 1999, 38, 43-58.

Camerer, C.F. Behavioral Game Theory: Experiments in Strategic Interaction. Princeton: Princeton University Press, 2003.

Cooley, C.H. Human Nature and the Social Order. New York: Schribners, 1922. 
Dana, J., Cain, D.M. and Dawes, R.M. What you don't know won't hurt me: Costly but quiet exit in dictator games. Organizational Behavior and Human Decision Processes 2006, 100,193-201.

Dana, J., Weber, R. and J. X. Kuang. Exploiting moral wriggle room: Behavior inconsistent with a preference for fair outcomes. Economic Theory 2007 (in press).

Ellingsen, T. and Johannesson, M. Sunk costs and fairness in incomplete information bargaining. Games and Economic Behavior 2005, 50, 155-177.

Ellingsen, T. and Johannesson, M. Promises, threats and fairness. Economic Journal 2004, 114, 397-420.

Fehr, E., Fischbacher, U. and Gächter, S. Strong reciprocity, human cooperation and the enforcement of social norms. Human Nature 2002, 13, 1-25.

Fehr, E. and Singer, T. The neuroeconomics of mind reading and empathy. American Economic Review Papers and Proceedings 2005, 95, 340-345.

Fessler, D.M.T. Shame in two cultures: Implications for evolutionary approaches. Journal of Cognition and Culture 2004, 4, 207-262.

Gaines, L.M., Duvall, J., Webster, J.M. and Smith, R.H. Feeling good after praise for a successful performance: the importance of social comparison information. Self and Identity 2005, 4, 373-389. 
Gintis, H. Strong reciprocity and human sociality. Journal of Theoretical Biology 2000, 206, $169-179$.

Gächter, S. and Fehr, E. Collective action as a social exchange. Journal of Economic Behavior and Organization 1999, 39, 341-369.

Hagen, E.H. and Hammerstein, P. Game theory and human evolution: A critique of some recent interpretations of experimental games. Theoretical Population Biology 2006, 69, 339348.

Haley, K.J. and Fessler, D.M.T. Nobody's watching? Subtle cues affect generosity in an anonymous economic game. Evolution and Human Behavior 2005, 26, 245-256.

Hatfield E, Cacioppo JT, Rapson RL. Emotional Contagion. New York: Cambridge University Press, 1993.

Hatfield, E., Hsee, C.K., Costello, J. and Denney, C. The impact of vocal feedback on emotional experience and expression. Journal of Social Behavior and Personality 1995, 10, 293-312.

Hoffman, E., McCabe, K.A., Shachat, K. and Smith, V.L. Preferences, property rights and anonymity in bargaining games. Games and Economic Behavior 1994, 7, 346-380. 
Henderlong, J. and Lepper, M.R. The effects of praise on children's intrinsic motivation: a review and synthesis. Psychological Bulletin 2002, 128, 774-795.

Henrich, J., Boyd, R., Bowles, S., Camerer, C., Fehr, E. and Gintis, H. Foundations of Human Sociality: Economic Experiments and Ethnographic Evidence from Fifteen Small-Scale Societies. New York: Oxford University Press, 2004.

Johannesson, M. and Persson, B. Non-reciprocal altruism in dictator games. Economics Letters 2000, 69, 137-142.

Koenigs, M., Young, L., Adolphs, R., Tranel, D., Cushman, F., Hauser, M. and Damasio, A. Damage to the prefrontal cortex increases utilitarian moral judgements. Nature 2007, 446, 908-911.

Masclet, D., Noussair, C., Tucker, S. and Villeval, M.C. Monetary and nonmonetary punishment in the voluntary contributions mechanism. American Economic Review 2003, 93, $366-380$

Noussair, C. and Tucker, S. Combining monetary and social sanctions to promote cooperation. Economic Inquiry 2005, 43, 649-660.

Nowak, M.A. Five rules for the evolution of cooperation. Science 2006, 314, 1560-1563.

Ostrom, E. Governing the Commons: The Evolution of Institutions for Collective Action. Cambridge: Cambridge University Press, 1990. 
Ostrom, E. and Walker, J. Neither markets nor states: Linking transformation processes in collective action arenas. In Mueller, D.C. (ed.): Perspectives on Public Choice: A Handbook 1997, 35-72. Cambridge: Cambridge University Press.

Scheff, T.J. Shame and conformity: The deference-emotion system. American Sociological Review 1988, 53, 395-406.

Singer, T., Seymour, B., O’Doherty, J.P., Stephan, K.E., Dolan, R.J. and Frith, C.D. Empathy for pain involves the affective but not sensory components of pain. Science 2004, 303, $1157-$ 1162.

Smith, A. The Theory of Moral Sentiments. $6^{\text {th }}$ Edition. London: A. Millar, 1790.

Stajkovic, A.D. and Luthans, F. Behavioral management and task performance in organizations: conceptual background, meta-analysis, and test of alternative models. Personnel Psychology 2003, 56, 155-194.

Webster, J.M., Duvall, J., Gaines, L.M. and Smith, R.H. The roles of praise and social comparison information in the experience of pride. Journal of Social Psychology 2003, 143, 209-232.

Xiao, E. and Houser, D. Emotion expression in human punishment behavior. Proceedings of the National Academy of Sciences 2005, 102, 7398-7401. 
Xiao, E. and Houser, D. Emotion expression and fairness in economic exchange. Working Paper, Interdisciplinary Center for Economic Science (ICES), George Mason University, 2007. 
APPENDIX 1: MESSAGES IN THE STUDY (The original messages were in Swedish. This appendix includes a translation of the messages).

\begin{tabular}{|c|c|c|}
\hline Donation & Message & $\begin{array}{l}\text { Evaluation of } \\
\text { the divider in } \\
\text { the message }\end{array}$ \\
\hline 0 & $\begin{array}{l}\text { So you choose to take all the money yourself, you greedy } \\
\text { bastard. I was just wondering if there was anyone who } \\
\text { would do that and the answer apparently is yes, apparently } \\
\text { people like you exist! Have a nice evening! }\end{array}$ & Disapproval \\
\hline 0 & $\begin{array}{l}\text { Thanks you greedy bastard. You will like it as investment } \\
\text { banker! I hope you will buy something nice }\end{array}$ & Disapproval \\
\hline 0 & Do you scream when you shit? & Disapproval \\
\hline 0 & $\begin{array}{l}\text { Shouldn't you at least be a bit loyal, I would at least have } \\
\text { left something! }\end{array}$ & Disapproval \\
\hline 0 & $\begin{array}{l}\text { You are very selfish, greedy and stupid!!!!!! I would really } \\
\text { need some money! }\end{array}$ & Disapproval \\
\hline 0 & Greedy bastard & Disapproval \\
\hline 0 & $\begin{array}{l}\text { Honestly! You must really be in deep shit if you think you } \\
\text { are worth the entire amount! A hot tip is to carry out a } \\
\text { household budget, income, expenses, use a cash-book and } \\
\text { do some planning and it will not be a problem to live on } \\
\text { CSN* in the future! }\end{array}$ & Disapproval \\
\hline 0 & $\begin{array}{l}\text { THANKS! Couldn't you have shared? You would still have } \\
\text { gotten } 60 \text { kronor without doing anything to deserve them. }\end{array}$ & Disapproval \\
\hline 0 & Cheapskate! & Disapproval \\
\hline 0 & You were a greedy bastard! & Disapproval \\
\hline 0 & $\begin{array}{l}\text { You greedy bastard! No but it's right, feel no pressure most } \\
\text { people would probably have done the same thing. But } \\
\text { come-on you could at least have put in } 20 \text { !!! I hope you will } \\
\text { enjoy your undeserved money!! You're lucky it's } \\
\text { anonymous. }\end{array}$ & Disapproval \\
\hline 0 & $\begin{array}{l}\text { Not even } 20 \text { ! To be sure rational. Buy me lunch instead? } \\
21042 ! ! !\end{array}$ & Disapproval \\
\hline 0 & I will come looking for you silly idiot! & Disapproval \\
\hline 0 & A pity that I know who you are!!! & Disapproval \\
\hline 0 & $\begin{array}{l}\text { Haha! I would have done the same thing! We students at } \\
\text { Stockholm School of Economics are probably rather similar. } \\
\text { A greedy bunch. }\end{array}$ & Neutral \\
\hline 0 & Thank you very much you greedy bastard & Disapproval \\
\hline 0 & You greedy bastard! & Disapproval \\
\hline 0 & Clown & Disapproval \\
\hline 20 & $\begin{array}{l}\text { OK, so this is fair according to you?? Imagine the reverse, } \\
\text { that you will receive } 20 \text { out of the possible } 120 \text { kronor... }\end{array}$ & Disapproval \\
\hline 20 & $\begin{array}{l}\text { Hi! Thank you for giving me some money, as I know that I } \\
\text { have difficulties myself to say no to extra money. However, } \\
\text { it would have been more fair if you had split them 50:50. }\end{array}$ & Approval \\
\hline 20 & $\begin{array}{l}\text { Thank you for the sympathy-twenty! I would have preferred } \\
\text { more, but what the hell, I'm not bitter. (I would have done }\end{array}$ & Neutral \\
\hline
\end{tabular}




\begin{tabular}{|c|c|c|}
\hline & $\begin{array}{l}\text { the same thing myself). I'm furthermore more bitter that I } \\
\text { didn't get any lunch today, so I would have preferred to be } \\
\text { in room A. I hope you will buy some good beers for the } \\
\text { money... I think I will do that anyway }\end{array}$ & \\
\hline 20 & $\begin{array}{l}\text { I would probably have done the same if I got the chance. } \\
\text { But you could have been a bit more generous... Like } 40 . .\end{array}$ & Neutral \\
\hline 20 & NO MESSAGE & \\
\hline 20 & $\begin{array}{l}\text { Thanks for the money! You made a generous choice by } \\
\text { giving me twenty. Personally I would probably have } \\
\text { pocketed the entire amount. I am going for some after-work } \\
\text { beer after this together with some friends. You can afford } \\
\text { that now. Tempted? Have a good day./nr. } 8\end{array}$ & Approval \\
\hline 20 & $\begin{array}{l}\text { Okay you fagot, } 20 \text { symbolic... Your karma would have } \\
\text { become much stronger if you had kept } 60 \text {, but I'm not } \\
\text { totally dissatisfied. Some time ago I could have bought a } \\
\text { small packet of cigarettes for the money, but now when they } \\
\text { only sell } 20 \text {-packs I have to pay } 20 \text { myself. But there is no } \\
\text { trouble with that as I'm heavily spoiled and I can always get } \\
\text { money from mum and dad instead. Dear allowance holder, } \\
\text { enjoy the hundred! Find me please, so that we can go on a } \\
\text { date and if I'm lucky I will marry rich! }\end{array}$ & Disapproval \\
\hline 20 & $\begin{array}{l}\text { You greedy bastard. Normally you give at least } 1 / 3 \text {. You } \\
\text { have to be a boy! The person to the right of you (nr 26) will } \\
\text { get a long and happy life. }\end{array}$ & Disapproval \\
\hline 20 & $\begin{array}{l}\text { Hi! I don't know if you 1. exists } 2 \text {. has received the same } \\
\text { information as me } 3 \text {. will receive this message. If you want } \\
\text { to know who the other person is and so on my name is } \\
\text { Pierre Jarmieus (seminar group 7, freshmen group 15). (the } \\
\text { union web...mail) Thanks for the bill }\end{array}$ & Neutral \\
\hline 20 & $\begin{array}{l}\text { Oh, oh! I was prepared for nothing, magnanimous, a golden } \\
\text { star. Hm, the girl two persons away received } 60 \text {. Difficult } \\
\text { trade-off if her counterpart is foolhardy or very } \\
\text { goodhearted... }\end{array}$ & Approval \\
\hline 20 & Generous boy/girl.... & Disapproval \\
\hline 40 & $\begin{array}{l}\text { Not even 50-50? You disloyal devil! Ha ha. Keep the } \\
\text { change you filthy animal. Have fun with the extra } 20 \\
\text { kronor. }\end{array}$ & Disapproval \\
\hline 40 & $\begin{array}{l}\text { I don't want to be greedy, but WHY do you deserve twice as } \\
\text { much as me for this time? }\end{array}$ & Disapproval \\
\hline 40 & 40 kronor was more than I expected, so thanks. & Approval \\
\hline 40 & Are you still living at home? Thanks anyway & Neutral \\
\hline 40 & I would have kept everything & Neutral \\
\hline 40 & THANKS! You owe me 20 kronor & Neutral \\
\hline 40 & Thanks for the money & Approval \\
\hline 40 & $\begin{array}{l}\text { Thanks! I thought I would get an empty envelope. However, } \\
\text { totally even would have been more fair or what do you } \\
\text { think. What would you have thought if you had been in } \\
\text { room B. I would have done that in any case (believe it or } \\
\text { not) }\end{array}$ & Approval \\
\hline
\end{tabular}




\begin{tabular}{|c|c|c|}
\hline 40 & $\begin{array}{l}\text { You did exactly what I would have done. Weird experiment } \\
\text { by the way }\end{array}$ & Approval \\
\hline 40 & Why didn't you take all the money? & Neutral \\
\hline 40 & You probably needed it more than me. & Neutral \\
\hline 40 & So, you think you are worth twice as much as me?! & Disapproval \\
\hline 60 & Thanks! I would have done the same thing. & Approval \\
\hline 60 & Thanks - you are a wonderfully fair person! & Approval \\
\hline 60 & Thanks! & Approval \\
\hline 60 & Thank you for your humanity & Approval \\
\hline 60 & Thanks! That was fraternally... & Approval \\
\hline 60 & Thanks, super! & Approval \\
\hline 60 & $\begin{array}{l}\text { That was fair 50/50. I hope your money will be useful! } \\
\text { Thanks! }\end{array}$ & Approval \\
\hline 60 & $\begin{array}{l}\text { Thank you so much! I would have understood if you had } \\
\text { taken all the money yourself, as it was your money for a } \\
\text { while. But as it was such easy money you probably thought } \\
\text { that you could as well be fair and split it, eventhough I will } \\
\text { never find out who you are.... So THANKS! }\end{array}$ & Approval \\
\hline 60 & $\begin{array}{l}\text { Just to be grateful and receive! With the help of your } \\
\text { generosity and your big heart I can tonight break the black- } \\
\text { pudding curse. No more pea soup! You have a standing } \\
\text { invitation to dinner at my place. The door is always open. } \\
\text { With love!/XXX }\end{array}$ & Approval \\
\hline 60 & NO MESSAGE & \\
\hline 60 & $\begin{array}{l}\text { I would have done the same if I was in that situation. The } \\
\text { task was actually more exciting for you as you were the one } \\
\text { making the choice. Exciting to be held accountable for } \\
\text { yourself./... }\end{array}$ & Approval \\
\hline 60 & Super, thanks! (mucho fair) & Approval \\
\hline 60 & $\begin{array}{l}\text { Thank you so much, that was generous! I would have taken } \\
\text { all the money myself! }\end{array}$ & Approval \\
\hline 60 & $\begin{array}{l}\text { Thanks! I was considering what I would have done, and } \\
\text { decided that I probably would have taken } 100 \text { kronor! The } \\
\text { reason was that that was how much I thought I would get. } \\
\text { But the "next" time I will probably think differently }\end{array}$ & Approval \\
\hline 60 & NO MESSAGE & \\
\hline 60 & $\begin{array}{l}\text { Thank you so much. To be honest I don't know if I would } \\
\text { have done the same knowing that it is anonymous. But I'm } \\
\text { grateful towards your benevolence. }\end{array}$ & Approval \\
\hline 60 & $\begin{array}{l}\text { Thanks, thanks. A diplomatic decision. Vi split the money } \\
\text { equally. I wonder if this is the average for all students at the } \\
\text { Stockholm School of Economics... }\end{array}$ & Approval \\
\hline 60 & $\begin{array}{l}\text { Thanks! That was just and fair. I would probably have taken } \\
\text { all myself, but I appreciate it! }\end{array}$ & Approval \\
\hline 60 & $\begin{array}{l}\text { THANKS! I would never have done that myself (why give } \\
\text { money to someone that you cannot get credit for?) but } \\
\text { magnanimous and generous of you! Live well! }\end{array}$ & Approval \\
\hline 60 & $\begin{array}{l}\text { You did the right thing! To be honest this was more than I } \\
\text { had expected from a student from Stockholm School of }\end{array}$ & Approval \\
\hline
\end{tabular}




\begin{tabular}{|c|c|c|}
\hline & $\begin{array}{l}\text { Economics. I hope that you will continue life with the same } \\
\text { outlook. }\end{array}$ & \\
\hline 60 & $\begin{array}{l}\text { Dear student friend? Instead of a "damned cheapskate" I can } \\
\text { with joy see that there in spite of all exist solidarity and } \\
\text { fairness in the world! It feels liberating! Haha, thanks for the } \\
\text { generosity! Chill }\end{array}$ & Approval \\
\hline 60 & $\begin{array}{l}\text { I would have done the same thing. Thanks. (On another } \\
\text { matter there lives a purple giraffe below a rock on my } \\
\text { cloud!) }\end{array}$ & Approval \\
\hline 60 & Thanks! That was a fair decision. & Approval \\
\hline 60 & Thanks for the generosity! & Approval \\
\hline 60 & $\begin{array}{l}\text { Dear A. I cordially thank you for this gift. In your position I } \\
\text { would probably have taken most of the money myself, but } \\
\text { to show that I'm not a total egoist I would probably have } \\
\text { left one } 20 \text { kronor bill. So I'm lucky that I wasn't you. Good } \\
\text { luck with your studies. Personally I think it's a little bit too } \\
\text { much right now. I don't know if you feel the same way, but } \\
\text { if you do remember Churchill: "The ability of success is to } \\
\text { go from failure to failure without loss of enthusiasm." }\end{array}$ & Approval \\
\hline 60 & There is hope for a better world! & Approval \\
\hline 60 & $\begin{array}{l}\text { Hallo! When I discovered what it was about I was a bit } \\
\text { disappointed as we had to go from A to B. But it was a good } \\
\text { outcome. What is going on otherwise? Maybe there will be } \\
\text { steak tonight, who knows... Here is a rabbit by the way: } \\
\text { (DRAWING OF RABBIT NOT INCLUDED HERE) }\end{array}$ & Approval \\
\hline 60 & NO MESSAGE & \\
\hline 60 & Thank you very much! It was fair and morally right. Good! & Approval \\
\hline 60 & $\begin{array}{l}\text { Hallo!!? You were a generous devil. I would have pocketed } \\
\text { everything myself. But thank you so much! You will surely } \\
\text { go to heaven }\end{array}$ & Approval \\
\hline 60 & Nicely acted! & Approval \\
\hline 60 & Fair! I would have done the same! & Approval \\
\hline 60 & I would have done the same thing. Super! & Approval \\
\hline 60 & $\begin{array}{l}\text { I thank you I thank you. Well done, know my lunch is paid } \\
\text { for }\end{array}$ & Approval \\
\hline 60 & Thanks! & Approval \\
\hline 60 & $\begin{array}{l}\text { Thank you very much for the money! It was cute of you to } \\
\text { split it equally between us! I would absolutely have done the } \\
\text { same thing! Have a wonderful afternoon/evening. }\end{array}$ & Approval \\
\hline 60 & $\begin{array}{l}\text { Thank you very much! It made me really happy. I would } \\
\text { probably only have left } 20 . . \text { Now there will be a few coffee } \\
\text { latte! }\end{array}$ & Approval \\
\hline 60 & $\begin{array}{l}\text { Thank you very much! It feels like a fair and wise decision } \\
\text { given the conditions. }\end{array}$ & Approval \\
\hline 60 & $\begin{array}{l}\text { So, here we share equally and fraternally in a true socialist } \\
\text { spirit... I don't know which incentives you had in your } \\
\text { situation, but I know that I would have done differently.. }\end{array}$ & Disapproval \\
\hline 60 & $\begin{array}{l}\text { Thanks! Really! I was really surprised. You didn't gain } \\
\text { from this, but it honours you. }\end{array}$ & Approval \\
\hline
\end{tabular}




\begin{tabular}{|l|l|l|}
\hline 60 & $\begin{array}{l}\text { Thanks! Unfortunately I must confess that you wouldn't } \\
\text { have received a krona from me. But if it's ever revealed } \\
\text { who you are, I will buy you a beer. }\end{array}$ & Approval \\
\hline 80 & Big thanks! GIRL? & Approval \\
\hline 120 & $\begin{array}{l}\text { Thanks, thanks. If you want to split 50/50 I will be outside } \\
\text { the main entrance for a while after the experiment! }\end{array}$ & \\
\hline 120 & Thanks! & Approval \\
\hline
\end{tabular}

* CSN is the national authority that handles the Swedish financial aid for students; i.e. loans and grants for students. 


\section{APPENDIX 2: EXPERIMENTAL INSTRUCTIONS}

The original instructions were in Swedish. This appendix reprints a translation of the instructions.

\section{INSTRUCTIONS (feedback group)}

Thank you for participating in this experiment. In the experiment each of you will be paired with another person in another room. You will not be told who this other person is, neither during nor after the experiment. There is an equal number of persons in each room (A and $B)$. This is room A (B). Every person in room A and Room B has received these instructions and a number that depicts which pair he/she belongs to. In the experiment every person in room A will decide how to divide SEK 120 between him/herself and the person in room B with whom he/she has been paired.

The experiment runs as follows. Every person in room A has received an envelope marked with the number of the person. All the envelopes contain six SEK 20 bills.

The experimenter asks one person at a time in room A to come forward and the person takes the envelope and goes behind the screen in room A. The envelope is then opened behind the screen where no one else can see what happens.

Behind the screen every person in room A has to decide how many bills, if any, to leave in the envelope. The person then pockets the remaining bills. No one else, including those conducting the experiment, will know what decision a particular person makes.

When the person behind the screen has made his/her decision he/she seals the envelope and puts it in the box marked "Mail" and returns to their seat.

When all envelopes have been handed in, the experimenter gives the envelopes to an assistant that is waiting outside of room A. The assistant takes the envelopes to room B and hands out each envelope to the counterpart in room B. Every person in room B opens the envelope and pockets the money in the envelope. The person also writes down how much money they received on the form marked "Results/Message", which has been given to every person in room $\mathrm{B}$.

Thereafter each person in room B has the opportunity to write a message to the person in room A on the form marked "Results/Message". The person in room B then puts the form marked "Results/Message" in the envelope and the assistant collects the envelopes. The persons in room B can then leave the room.

The assistant brings the envelopes to room A and gives them to the experimenter; the assistant then leaves the room. The experimenter hands out each envelope to the respective person in room A. The person in room A takes out the form marked "Results/Message" and reads through the message and then folds the form. The experimenter then passes round the box marked "Mail" and every person in room A puts the form marked "Results/Message" in the box (note that as these forms are not market with the number of the pair, the results cannot be linked to the number of a specific person). The experiment is then over and the persons in room A can leave the room. 
INSTRUCTIONS (control group)

Thank you for participating in this experiment. In the experiment each of you will be paired with another person in another room. You will not be told who this other person is, neither during nor after the experiment. There is an equal number of persons in each room (A and B). This is room A (B). Every person in room A and Room B has received these instructions and a number that depicts which pair he/she belongs to. In the experiment every person in room A will decide how to divide SEK 120 between him/herself and the person in room B with whom he/she has been paired.

The experiment runs as follows. Every person in room A has received an envelope marked with the number of the person. All the envelopes contain six SEK 20 bills.

The experimenter asks one person at a time in room A to come forward and the person takes the envelope and goes behind the screen in room A. The envelope is then opened behind the screen where no one else can see what happens.

Behind the screen every person in room A has to decide how many bills, if any, to leave in the envelope. The person then pockets the remaining bills. No one else, including those conducting the experiment, will know what decision a particular person makes.

When the person behind the screen has made his/her decision he/she seals the envelope and puts it in the box marked "Mail". The person can then leave the room.

When all envelopes have been handed in, the experimenter gives the envelopes to an assistant that is waiting outside of room A. The assistant takes the envelopes to room B and hands out each envelope to the counterpart in room B. Every person in room B opens the envelope and pockets the money in the envelope. The person also writes down how much money they received on the form marked "Results", which has been given to every person in room B, and then folds this form.

The assistant then passes round the box marked "Mail" and every person in room B puts the form marked "Results" in the box (note that as these forms are not market with the number of the pair, the results cannot be linked to the number of a specific person). The experiment is then over and the persons in room B can leave the room. 
TABLES

Table 1. Experimental results.

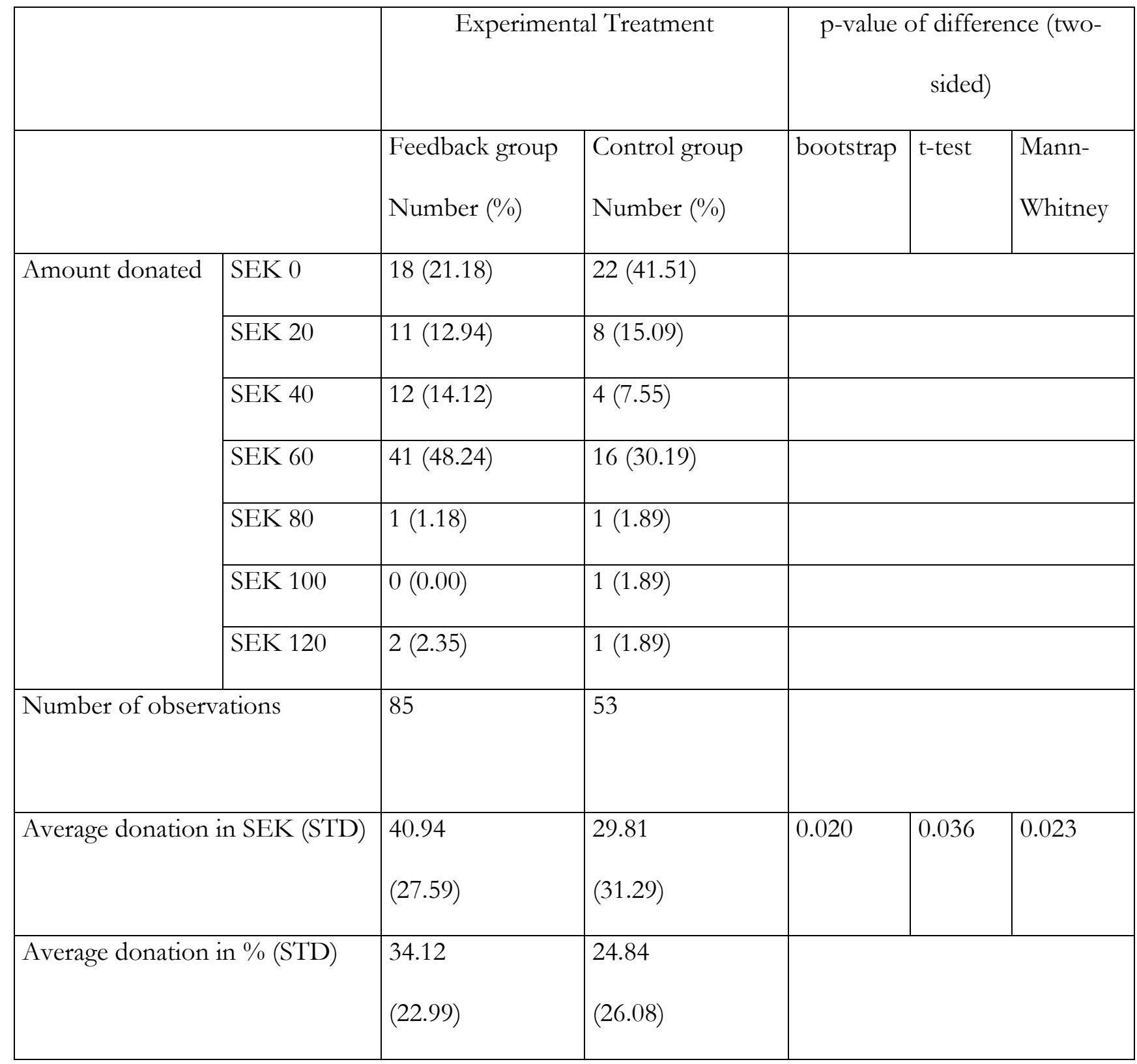




\section{FIGURES}

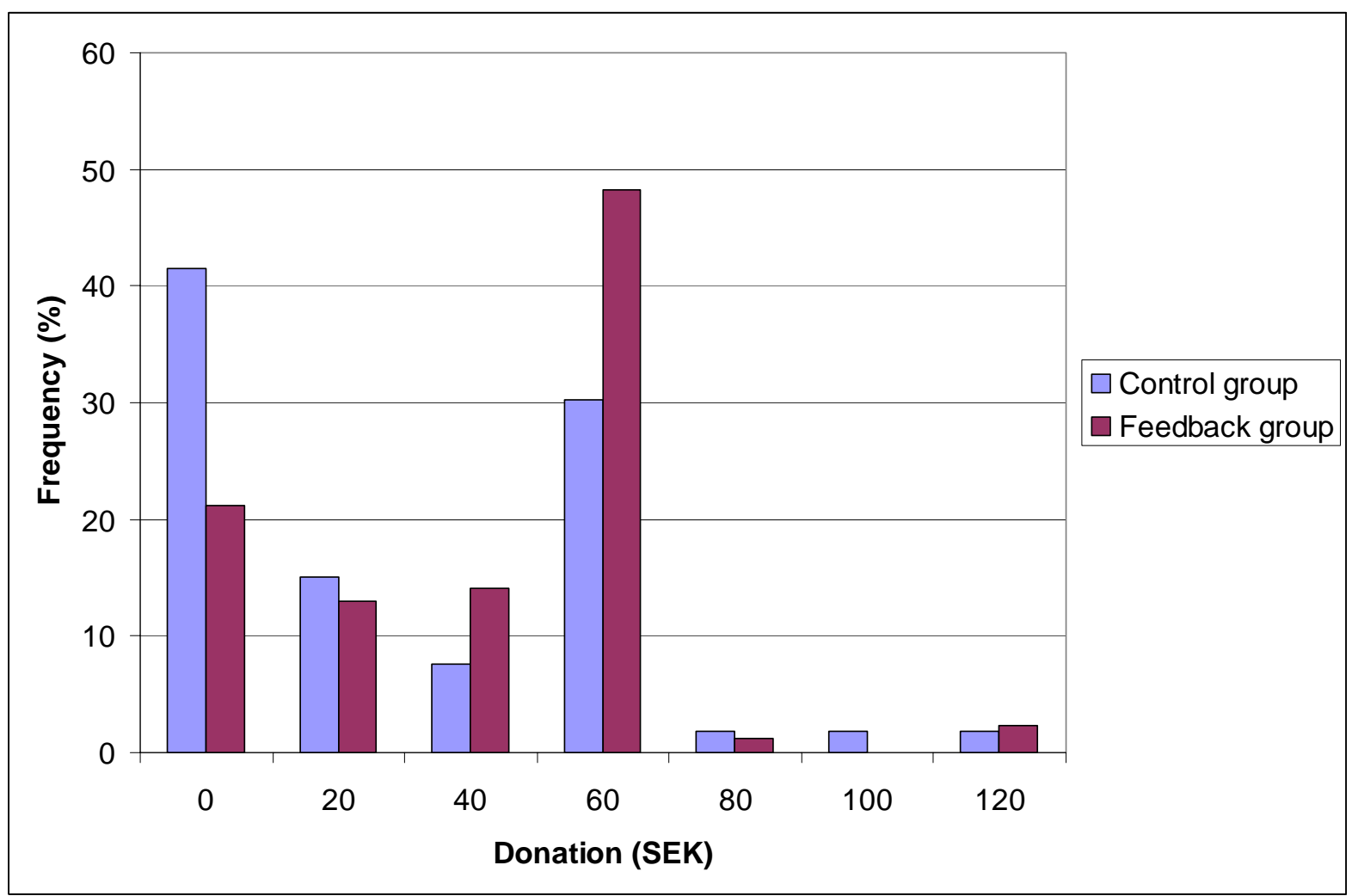

Figure 1. The distribution of donations in the experiment. 